\title{
OPTIMIZING THE COOLING ENERGY CONSUMPTION BY THE PASSIVE TRADITIONAL FAÇADE STRATEGIES IN HOT DRY CLIMATE
}

\author{
${ }^{1}$ Messaouda RAIS, ${ }^{2}$ Adel BOUMERzOUG, ${ }^{3}$ Miklos HALADA ${ }^{*},{ }^{4}$ Leila SRITI \\ ${ }^{1}$ Breuer Marcell Doctoral School, Faculty of Engineering and Information Technology \\ University of Pécs, Boszorkány u. 2, H-7624 Pécs, Hungary \\ e-mail: messaouda.raiss@gmail.com \\ ${ }^{2,4}$ LACOMOFA Laboratory, Institute of Architecture, University Mohamed Khider Biskra \\ BP 145 RP, 07000, Biskra Algeria \\ e-mail: ${ }^{2}$ boumerzoug.adel@hotmail.com, ${ }^{4}$ sritileila@yahoo.fr \\ ${ }^{3}$ Institute of Architecture, Faculty of Engineering and Information Technology, University of \\ Pécs, Boszorkány u. 2, H-7624 Pécs, Hungary, e-mail: halada@mik.pte.hu
}

Received 29 January 2018; accepted 24 July 2018

\begin{abstract}
The building façade becomes an integral part of the concept for adaptation of the building to the climate conditions; it should be able to respond and adapt its properties and components with the immediate environment.

In the hot and dry climate in Algeria, the contemporary building design, materials, and techniques applied do not properly address the local climate conditions and the final energy consumption. Contrary to this, in traditional building practice, the local materials and passive strategies are used, which responded to the environmental context.

This study is focused on improvement of the cooling energy consumption of the contemporary buildings in Biskra City, Algeria. The traditional climatic façade solutions are investigated in order to adapt them to the contemporary buildings. To define and optimize the solutions, dynamic simulation with Vi-Suite add-on Blender 3D software was used. The results show a significant reduction in the cooling energy consumption, which confirms the use of the traditional techniques that can considerably improve the building efficiency.
\end{abstract}

Keywords: Energy consumption, Cooling, Traditional façade solutions, Improvement of contemporary buildings

\section{Introduction}

The building inventory in Algeria consumes a large amount of energy accounting for more than $33 \%$ of the overall energy consumption; this value steadily increased in recent years (1.9\% between 2015 and 2016), and in turn, this type of consumption is a

${ }^{*}$ Corresponding Author 
primary contributor to the global environmental degradation in the country [1]. Climatic conditions have a significant impact on the building performance and energy consumption. In hot and dry Algerian regions, excess solar gains and high outside temperatures, especially in summer, resulting in an indoor discomfort, thus high cooling energy consumption [2], [3].

The building façade as exposed to outside part of the building boundary separates the outdoor from the sheltered environment. It has a crucial role in the conception of optimization of the buildings with respect to the energy consumption and adaptation to the climate conditions [4]. In contemporary buildings, the façade design and construction practice were quoted from a different environment [5]. Consequently, these buildings are not adapted to the local climate conditions and their final energy consumption is rather excessive. Contrary to this, traditional buildings are good examples for an appropriate response to the local climate. These buildings ensure the required climate comfort conditions in interior spaces and energy conservation by using adaptive strategies. In this context, traditional models can offer key lessons about the best solutions to confront these concerns in contemporary applications [6].

In this study, solutions from traditional architecture in hot and dry regions are selected and analyzed in order to define their advantages and integrate them in contemporary residential buildings. The study aims, also, to improve the responsiveness of the façade and to optimize its energy performance.

\section{The climatic solutions of the traditional façade}

The traditional architectural façade in a hot and dry climate consists of many adapted solutions to climate, giving a general good comfort condition especially in the hot summer period, which included a cooling, passive strategy, good thermal mass, natural ventilation, and a specific opening dimensions with shading strategies [7].

\subsection{Traditional wall}

The traditional façade is characterized by the use of a massive wall construction made by natural building materials which included rubble, earth, rammed earth, adobe bricks, etc. (Fig. 1a). Given proper thickness, the wall will have the ability to reserve the extreme diurnal temperature, and transfer the heat absorbed externally during the day into the structure, and then doing the opposite during the night. The thickness of the wall in the studied region was $60 \mathrm{~cm}$ [8]. Fig. $1 b$ shows a wall section of a traditional house in Biskra.

\subsection{Window properties}

Windows opening is often arranged for the purposes of admission of the air flow, direct and indirect sunlight, and to provide views. In hot and dry climates, it is hard to combine these three functions in one architectural conception. Several solutions were used to obtain a compromise solution. The Moucharabieh is one of the elements that 
appear strongly in the traditional façade of hot and dry regions [9]. This was a wood element with a lattice opening, where a passive cooling system can be arranged Fig. 2.

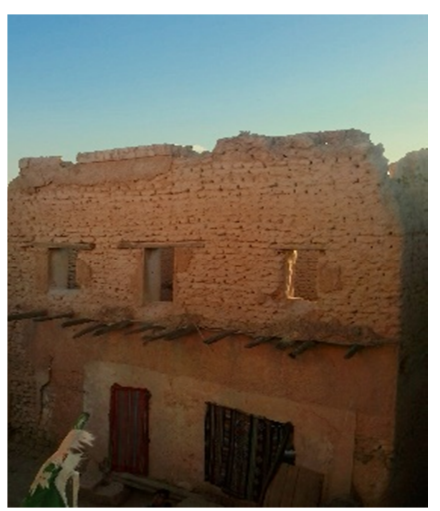

a)

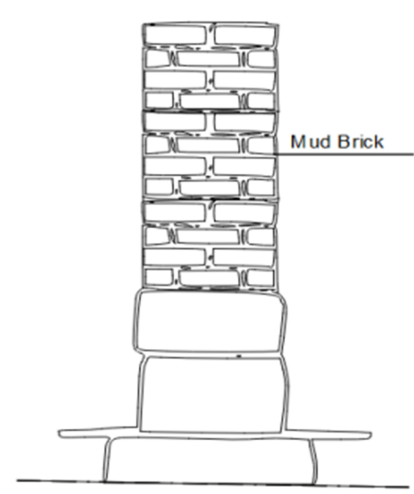

b)

Fig. 1. a) A traditional house in Biskra, b) Section of the exterior wall (Source: Authors)

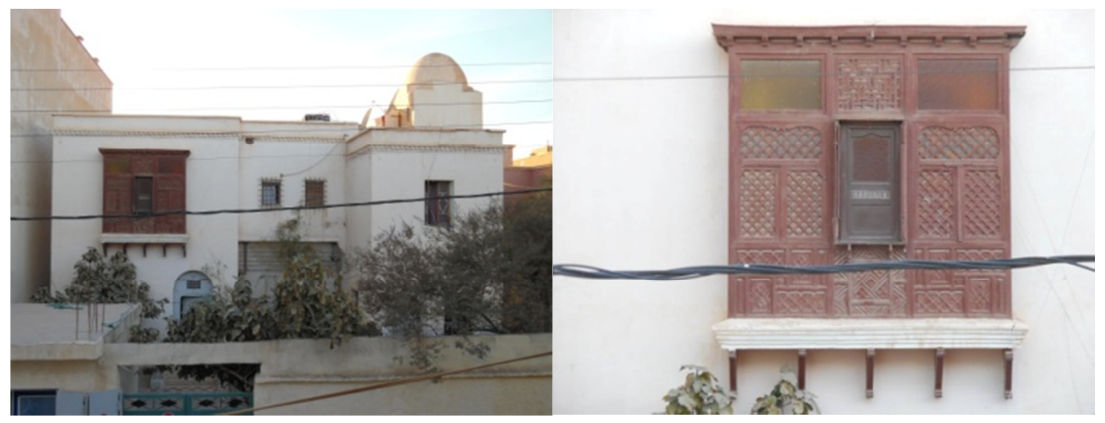

Fig. 2. Typical Moucharabieh in a traditional house in Biskra (Source: Authors)

\section{The contemporary residential building in Biskra-Algeria}

Biskra city is characterized by different styles of building from different historical periods. This city is classified by four periods: Traditional, colonial, independence, and contemporary building period [10].

This study focuses on the contemporary collective residential building, and the traditional housing, due to the rapture presented between the two periods. Fig. 3 shows a typical residential building in the city. The recent building typology calls for a new architectural conception that uses different materials and techniques, which quoted from another environment that does not serve the hot and dry climate region. It is mainly the concrete material (structure posts-beams and aerated concrete blocks), with a lesser wall thickness, different window typology, etc. Those techniques are known for its multiple advantages, ease of implementation, significant mechanical resistance acquired in the short term, but these are affecting the energy consumption. 


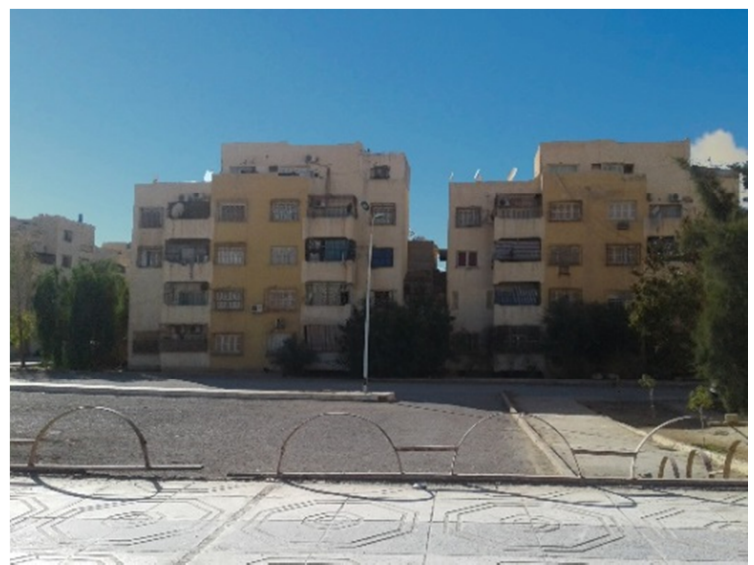

Fig. 3. Typical contemporary residential building in Biskra,Algeria (Source: Authors )

\section{Methodology}

As it is presented in Fig. 4, this methodology focuses on optimizing the cooling energy consumption of a typical contemporary residential building in Biskra City, through the selection of passive strategies of a traditional façade in the same context, in order to integrate and replace them in the contemporary residential building.

During the analysis, dynamic simulations will be carried out, in order to assess building cooling energy performance, using VI-suite software, that controls the external applications Radiance, Energy Plus and Matplotlib to conduct energy performance analysis across the free open-source Blender 3D [11].

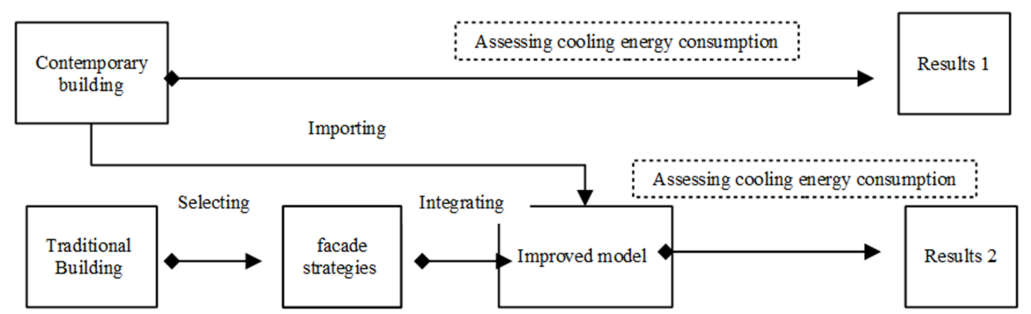

Fig. 4. Diagram of the methodology process (Source: Authors)

\subsection{Case study presentation}

The study context is focused on the city of Biskra, located in north-eastern of Algeria on the northern edge of the Sahara Desert at a latitude of $34^{\circ} 48^{\prime}$ north and a longitude of $5^{\circ} 44^{\prime}$ east. It rises to an altitude of 86 meters, Fig. 5.

Depending on the Köppen-Geiger climate classification Biskra city is characterized by a hot desert climate, which means very hot summers and mild winters [12]. 


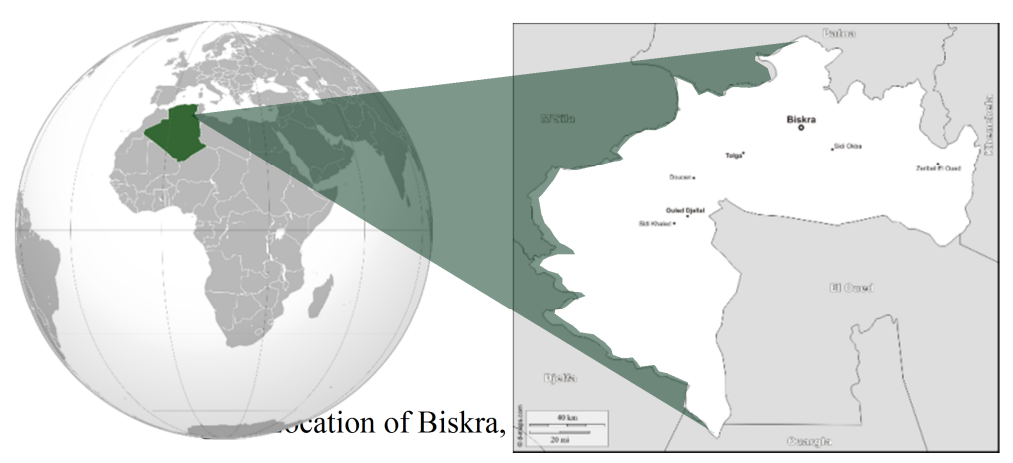

Fig. 6 illustrates the monthly temperatures of the city of Biskra for the year 2017 . Note that the minimum temperature in the month of July during the summer period is about $27.9^{\circ} \mathrm{C}$, and the maximum temperature is $40.9^{\circ} \mathrm{C}$, [13].

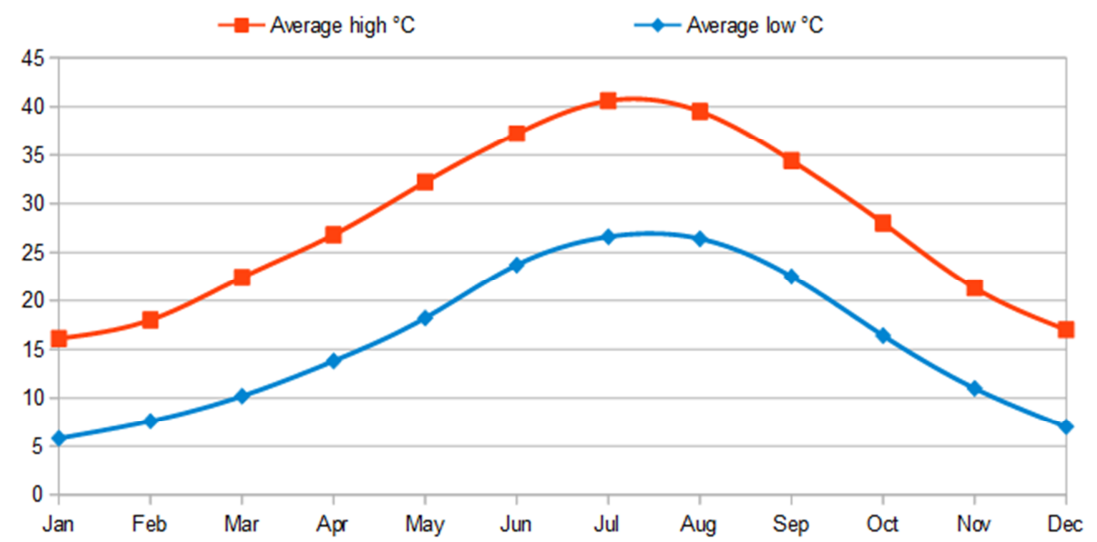

Fig. 6. The monthly average temperatures of city Biskra in 2017, (Source: Authors)

\subsection{Contemporary building reference}

In order to evaluate the energy cooling demand, a typical reference building has been chosen, which is situated in EL AMEl district Biskra City, Fig. $7 a$.

The building is composed of four-stories in two blocks, which comprises of sixteen F3 dwellings. Each block has its entrances, Fig. $7 b$.

The constructive system is done by posts-beams and solid slabs of reinforced concrete. The separation between the two houses is ensured by a reinforced concrete wall of $15 \mathrm{~cm}$. The exterior building walls are built to aerated concrete blocks, pierced by small windows to ventilate and illuminate the different rooms. All windows are protected from sunlight by sunshades. 


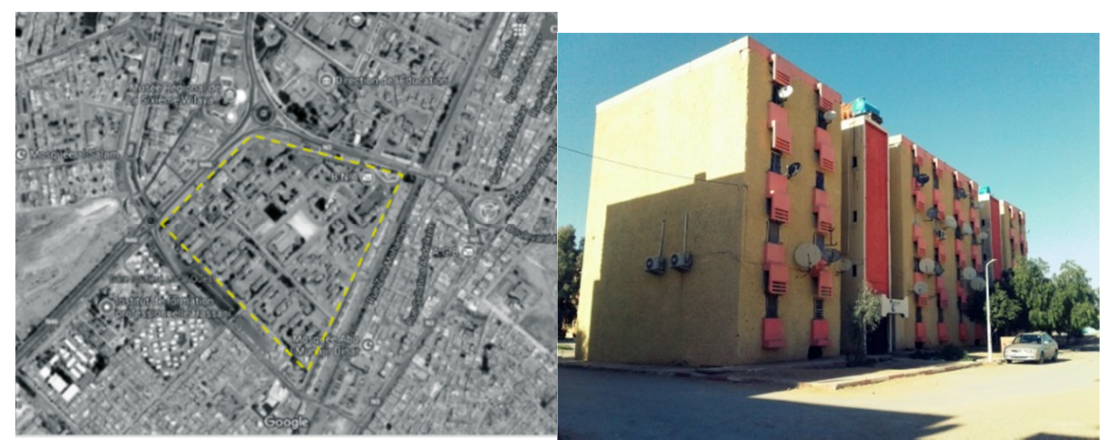

a)

b)

Fig. 7. a) Location of the building; b) Picture of the building (Source: Authors)

The story contains two dwellings, with a similar spatial composition: living room, two rooms, a kitchen, a laundry room, a toilet, and a bathroom. The total area is $92.13 \mathrm{~m}^{2}$, and a ceiling height of $2.70 \mathrm{~m}$, Fig. 8 .

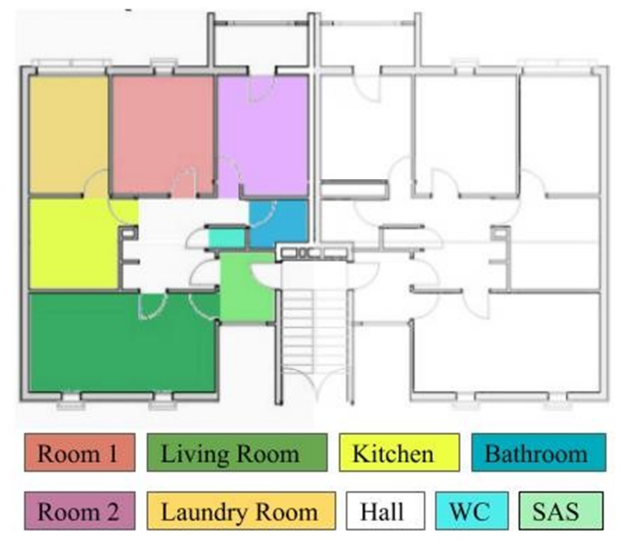

Fig. 8. Plan of the apartment (Source: Authors)

\subsection{Evaluation process}

Currently, in the building energetic field, predictive numerical models have been widely used. It is considered one of the most important decision tool in the environmental design process [14], [15].

Blender 3D software has been used for modeling, and building information has been included by VI-suite. The fixed simulated period is 1 April - 31 October, which presents the discomfort period in this context. The building cooling service system are integrated, based on the information announced by the government of Algeria to save energy, the cooling system turns on if the temperature is above $25^{\circ} \mathrm{C},[16]$. 
The evaluation process is passed through two main steps before running the simulation. The first step was a survey that included questions based on determining the time of cooling needs by the occupants, and the most heated area in the apartment. The second step was a sunlit time simulation using the VI-suite, to specify the most heated apartment in the building.

Survey

The results show that the space that has the most number of air conditioning units in the different apartments is the living room (see Table I), and the most common usage time of air conditioning is between 20:00 - 8:00, (Fig. 9).

\section{Table I}

The distribution of the air conventioneer in the apartments

\begin{tabular}{|c|c|c|c|c|}
\hline Kitchen & Hall & Room 1 & Room 2 & Living room \\
\hline 0 & 2 & 7 & 6 & 12 \\
\hline
\end{tabular}

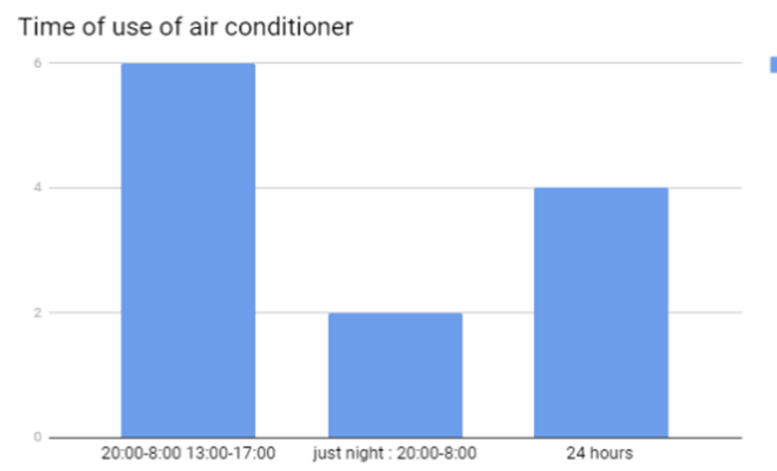

Fig. 9. Duration time of using air conditioning by the occupant (Source: Authors)

\section{Assessing sunlit-time}

In order to determine the most exposed apartment in the whole building, a sunlittime simulation is applied using VI-suit software. The result shows that the most exposed apartment to solar radiation is the southwest apartment on the fourth floor. The exposure of this apartment during this period on both façades reaches the maximum compared to others, Fig. 10.

\subsection{Simulation processes}

Depending on the results of the survey and the sunlit-time simulation, the area chosen for assessing cooling energy demand is the 'living room' of the southwest 
apartments, for the reason that it was the space that contained the most air condition units in the building and the most exposed to the solar radiation.

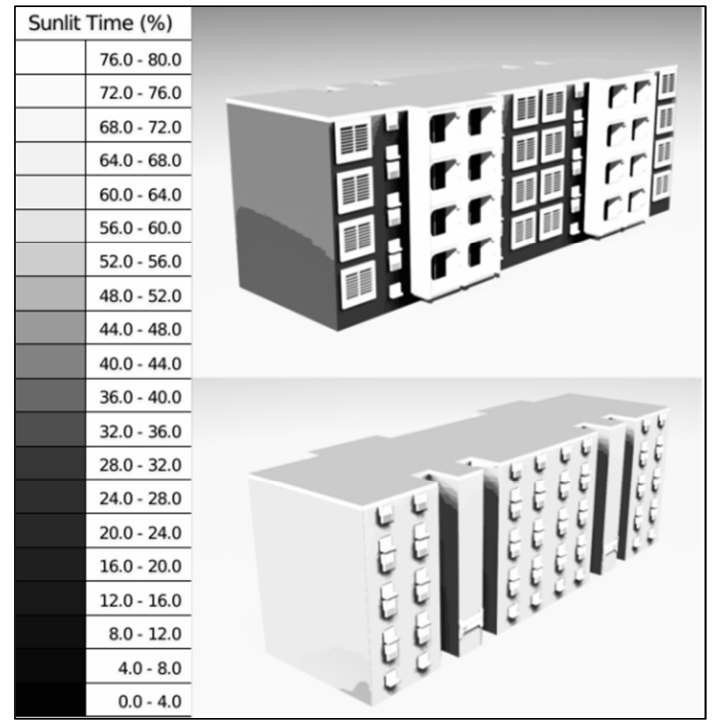

Fig. 10. Sunlit time simulation results (Source: Authors)

The simulation processes are passed through two main steps. The first step is to assess the cooling energy performance of the living room in the existing contemporary building, with the introduction of the physical property of its materials [17], Table II.

The second step is to generate two scenarios. The first scenario has been defined based on replacing the external wall material and reinforced concrete shading element by the traditional wall material (Compressed Mud Brick), and the window protection element (Moucharabieh) (see Fig. 11). The main selected traditional strategies properties are presented in Table III [18]. The third scenario was to remove the Moucharabieh from the simulation to define its exact contribution to improving the energy consumption compared to the second scenario.

\section{Discussion of results}

In the first step, the simulation results showed the cooling energy consumption of the existing case study in the simulated period, reached $6021.1 \mathrm{kWh}$, is equivalent to $297.5 \mathrm{kWh} / \mathrm{m}^{2}$.

In the second step, in the first scenario, the cooling energy load decreased to $5114.0 \mathrm{kWh}$, is equivalent to $252.7 \mathrm{kWh} / \mathrm{m}^{2}$. Thus, those two strategies contribute to significant reduction of the cooling energy consumption, estimated 15\%. Fig. 12 shows a comparison between the case study and the first scenario. 
Table II

Thermo-physical characteristics of contemporary façade

\begin{tabular}{|c|c|c|c|c|c|c|}
\hline \multirow{5}{*}{$\begin{array}{l}\text { Façade } \\
\text { building } \\
\text { reference }\end{array}$} & $\begin{array}{l}\overrightarrow{0} \\
\stackrel{\overrightarrow{0}}{0} \\
\frac{\overrightarrow{0}}{0}\end{array}$ & 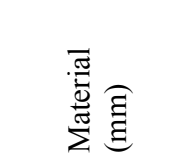 & 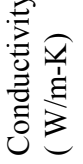 & 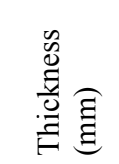 & 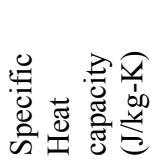 & 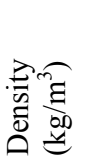 \\
\hline & \multirow{3}{*}{$\begin{array}{l}\text { External } \\
\text { Wall }\end{array}$} & $\begin{array}{l}\text { Cement } \\
\text { Cladding }\end{array}$ & 1.4 & $20 \mathrm{~mm}$ & 1080 & 2200 \\
\hline & & $\begin{array}{l}\text { Concert } \\
\text { aerated block }\end{array}$ & 1.25 & $200 \mathrm{~mm}$ & 1080 & 1300 \\
\hline & & $\begin{array}{l}\text { Air Gap } \\
\text { Plaster Board }\end{array}$ & $\begin{array}{l}1 \\
0.35\end{array}$ & $\begin{array}{l}40 \mathrm{~mm} \\
70 \mathrm{~mm}\end{array}$ & $\begin{array}{l}/ \\
950\end{array}$ & $\begin{array}{l}1 \\
936\end{array}$ \\
\hline & $\begin{array}{l}\text { Shading } \\
\text { Element }\end{array}$ & $\begin{array}{l}\text { Reinforced } \\
\text { concrete }\end{array}$ & 1.75 & $200 \mathrm{~mm}$ & 1080 & 2350 \\
\hline
\end{tabular}

Table III

Thermo-physical parameters of the improved façade

\begin{tabular}{|c|c|c|c|c|c|c|}
\hline \multirow{3}{*}{ 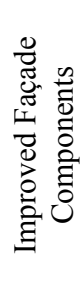 } & 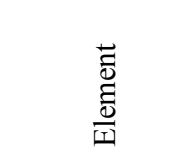 & 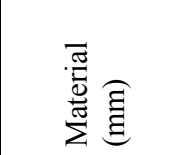 & 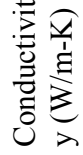 & 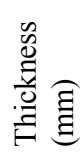 & 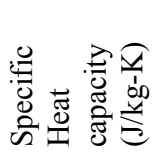 & 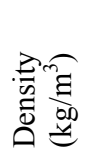 \\
\hline & Wall & $\begin{array}{l}\text { Compressed } \\
\text { Mud Brick }\end{array}$ & 0.9 & 500 & 1426.0 & 2500.0 \\
\hline & Moucharabieh & Lattice wood & 0.17 & 15 & 2000 & 740 \\
\hline
\end{tabular}

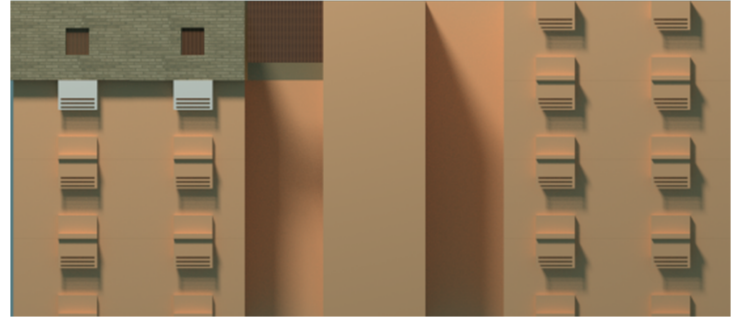

a)

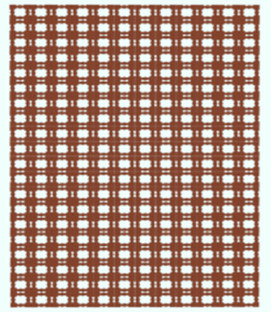

b)

Fig. 11. a) The optimized façade components, b) the Moucharabieh, (Source: Authors)

In the second scenario, the improved model without integrating the sun protection Moucharabieh reached $5273.9 \mathrm{kWh}$ is equivalents to $260.6 \mathrm{kWh} / \mathrm{m}^{2}$. This proves that a Compressed Mud Brick for the external wall can reduce $12 \%$ of the cooling consumption; therefore a Moucharabieh can contribute with $3 \%$ of reduction (see Fig. 13). 


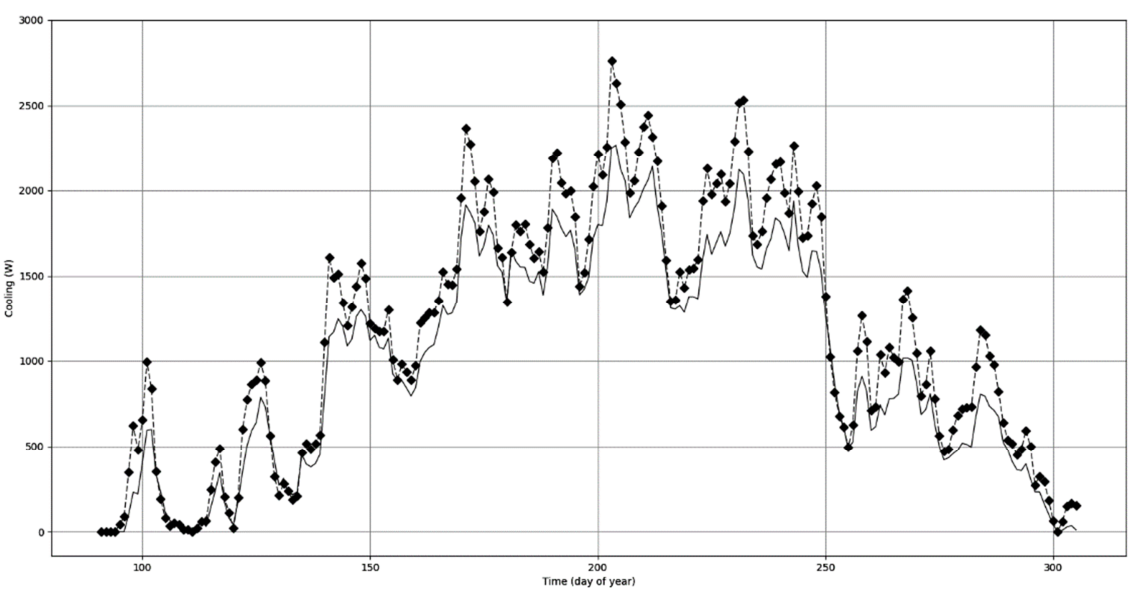

Existing building reference,

Scenario 1 optimized building

Fig. 12. Simulation results of the cooling energy consumption of the case study and the first scenario (Source: Authors)

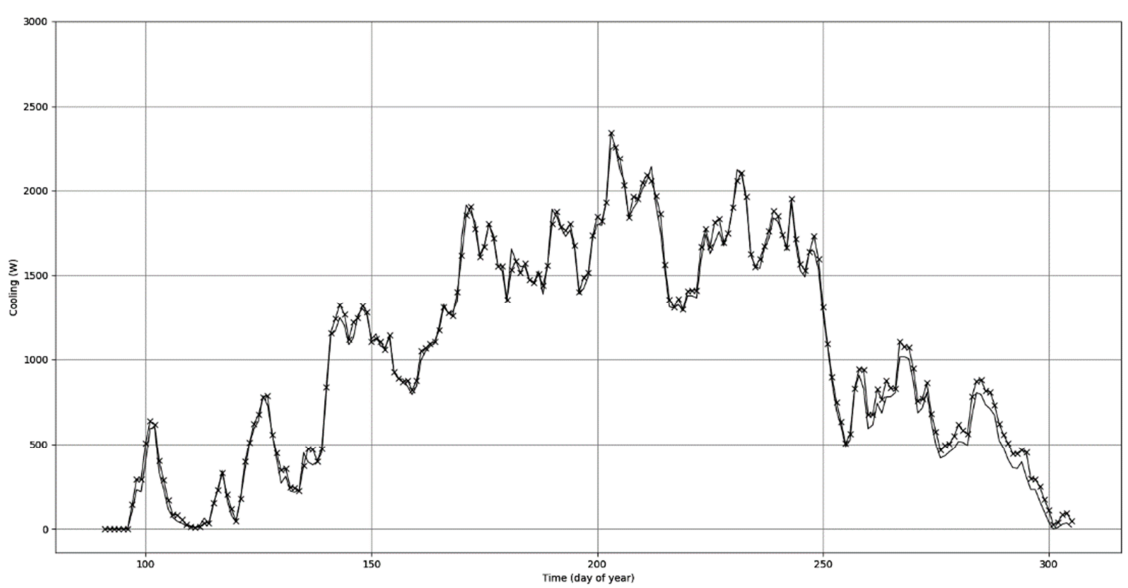

Scenario 1, optimized building,

Scenario 2, optimized building without Moucharabieh

Fig. 13. Simulation results of the cooling energy consumption of the first and second scenarios. (Source: Authors)

These results are due to the deference of the included physical proprieties of the wall external and the Moucharabieh that serves to reduce the heat transfer, and the direct solar irradiation impact. Table $I V$ shows a comparison between the estimated values of the cooling energy consumption of the two steps; the existing model, the improved model with and without a Moucharabieh. 
Table IV

Comparison between the estimated cooling energy consumption of the two scenarios

\begin{tabular}{|l|l|l|}
\hline \multicolumn{1}{|c|}{ Simulation steps } & $\mathrm{kWh}$ & $\mathrm{kWh} / \mathrm{m}^{2}$ \\
\hline Step 1: Existing Building & 6021.1 & 297.5 \\
Step 2: Scenario 1, optimized building: wall material/with & 5114.0 & 252.7 \\
$\begin{array}{l}\text { Moucharabieh } \\
\text { Step 2: Scenario 2, optimized building: wall material/without } \\
\text { Moucharabieh }\end{array}$ & 5273.9 & 260.6 \\
\hline
\end{tabular}

\section{Conclusion}

The results revealed that the façade components have a significant influence on the energy performance. A traditional façade in hot and dry climate, which contained a compressed mud brick wall and Moucharabieh, plays a big role on slowing-down the heat transfer and minimizing the penetration of the direct sun irradiation. Therefore, the reduction of the cooling energy consumption of the building can reach $15 \%$.

Finally it was concluded, that the integration of the traditional passive strategies in the contemporary building façade design can be a crucial parameter in sustainable and energy efficient architecture.

\section{Acknowledgements}

The Authors would like to thank Dr. Ryan Southall researcher and developer of VIsuite Add-on of Blender 3D, Britain University, Department of Architecture, for his help and great support.

\section{Open Access statement}

This is an open-access article distributed under the terms of the Creative Commons Attribution 4.0 International License (https://creativecommons.org/licenses/by/4.0/), which permits unrestricted use, distribution, and reproduction in any medium, provided the original author and source are credited, a link to the CC License is provided, and changes - if any - are indicated. (SID_1)

\section{References}

[1] Bilan_Energetique_National_2016_edition_2017, Ministry of Energy and Mining, Algeria, http://www.energy.gov.dz/francais/uploads/2017/Bilans_et_statistiques_du_secteur/BilanEnergetique/Bilan_Energetique_National_2016_edition_2017.pdf, (last visited 15 March 2018).

[2] Bouchaib S. Algerian portal of renewable energies (in French), http://portail.cder.dz/, (last visited 12 March 2018) 
[3] Ben Bacha C., Bourbia F. Effect of kinetic façades on energy efficiency in office buildings - hot dry climates, 11th Conference on Advanced Building Skins, Bern, Switzerland, 10-11 October 2016, pp. 458-468.

[4] Hausladen G., De Saldanha M., Liedl P. ClimateSkin: Building-skin concepts that can do more with less energy, Birkhäuser, 2008.

[5] Radha C. H., Kistelegdi I. Thermal performance analysis of Sabunkaran residential buildings typology, Pollack Periodica, Vol. 12, No. 2, 2017, pp. 151-162.

[6] Motealleh P., Zolfaghari M., Parsaee M. Investigating climate responsive solutions in vernacular architecture of Bushehr City, HBRC Journal, 2016, (in Press) doi.org/10.1016/j.hbrcj.2016.08.001.

[7] Daraf L., Khalafalla B., Hafid L. Urben and architectural sustainability indicators use energy hot climate areas in Algeria, Annals of the University of Oradea, Geography Series, Vol. 26, No. 1, 2016, pp. 71-85.

[8] Haoui S., Chergui S. Earth, stone and wood in the vernacular architecture of the Aures and Ziban: Materials of complementary use, J. Mater. Environ. Sci, Vol. 7, No. 10, 2016, pp. 3522-3531.

[9] Fathy H. Natural energy and vernacular architecture, The University of Chicago Press, 1986.

[10] Sriti L. Domestic architecture in its various aspects form, use, representation (in French) PhD Thesis, University Mohamed Khider, Biskra, 2013.

[11] Southall R., Biljecki F. The VI-Suite: A set of environmental analysis tools with geospatial data applications, Open Geospatial Data, Software and Standards, Vol. 2, No. 23, 2017, pages 13.

[12] Peel M. C., Finlayson B. L., McMahon T. A. Updated world map of the Köppen-Geiger climate classification, Hydrology and Earth System Sciences Discussions, Vol. 11, 2007, pp. 1633-1644.

[13] Climatology of the year 2017 in Biskra -Infoclimat, (in French) https://www.infoclimat.fr/ climatologie/annee/2017/biskra/valeurs/60525.html, (last visited 23 January 2018).

[14] De Boeck L., Verbeke S., Audenaert A., De Mesmaeker L. Improving the energy performance of residential buildings: A literature review, Renewable and Sustainable Energy Reviews, Vol. 52, 2015, pp. 960-975.

[15] Baranyai B., Bachmann B., Kistelegdi I. Simulation-supported design of a Hungarian national sports center, Pollack Periodica, Vol. 11, No. 1, 2016, pp. 113-127.

[16] Consomate better and pay less Consommez (in French) http://www.sda.dz/ $\mathrm{Fr} /$ ?page $=$ article\&ida=64, (last visited 13 March 2018).

[17] The regulatory technical document, Residential-rules of calculation of the heat supply in the buildings, (in French) DTR C3-2, 1997.

[18] Salima A. A. Thermal performance of the earth materials for sustainable residential building in arid and semi-arid climate: case study Timimoum. (in French) MSc Thesis, University Mouloud Maameriof Tizi Ouzou, 2012. 